\title{
Molecular Detection and Characterization of Infectious Laryngotracheitis Virus in Backyard Chickens in Turkey
}

\author{
Recep KALIN ${ }^{*}$, Turhan TURAN ${ }^{2}$, Hakan IŞIDAN ${ }^{2}$ \\ ${ }^{1}$ Sivas Cumburiyet University, Faculty of Veterinary Medicine, Department of Microbiology, Sivas, Turkey \\ ${ }^{2}$ Sivas Cumburiyet University, Faculty of Veterinary Medicine, Department of V irology, Sivas, Turkey
}

\begin{abstract}
Gallid herpesvirus I (GaHV1) is etiological agent of infectious laryngotracheitis (ILT) and ILT is one of the important disease that included in respiratory infections of chickens. Few studies have been conducted in Turkey and there is no data about the existence of ILT in backyards. The purpose of the study was to document the detection and characterization of GaHV1 in backyard chickens using PCR, RFLP and sequencing. Of the163 tracheal swap samples which were taken from 43 backyard flocks $5(3.07 \%)$ were found to be positive for ILT infection. Positivity was $4.65 \%(2 / 43)$ at flock level. The nucleic acid sequences of the ICP4 gene compared with ILTV sequences in GenBank and the level of identity differed from 96.82 to $100 \%$. When the sequences of samples compared with TCO strains $99.77-100 \%$ homology was observed. The virtual RFLP analysis with the HgaI restriction enzyme characterized strains as having a pattern similar to the vaccine strain TCO. This is the first study that presents presence and characterization of GaHV1 in backyards. Large scale studies are needed to estimate prevalence of ILT in Turkey. Chickens should be monitored and growers should avoid to contacting vaccinated birds with non-vaccinated chickens, to control ILTV outbreaks.
\end{abstract}

Keywords: Backyard, GaHV1, infectious laryngotracheitis, RFLP, sequencing

\author{
$* * *$ \\ Türkiye'deki Köy Tavuklarında İnfeksiyöz Laringotrakeitis Virüsünün Moleküler Tespiti ve \\ Karakterizasyonu
}

ÖZ

Gallid herpesvirüs I (GaHV1), infeksiyöz laringotrakeitisin (ILT) etiyolojik ajanıdır ve ILT, tavukların solunum yolu enfeksiyonları arasında yer alan önemli hastalıklardan biridir. Türkiye'de çok az çalışma yapılmış ve köy tavuklarında ILT'nin varlığına dair veri bulunmamaktadır. Çalısmada, köy tavuklarında PCR, RFLP ve sekans verileri kullanarak GaHV1'in tespitini ve karakterizasyonu amaçlandı. Toplamda 43 köy tavuğu işletmesinden alınan 163 trakeal swap örneğinin 5'inde (\% 3,07) ILT enfeksiyonu pozitif bulundu. Sürü düzeyinde pozitiflik \% 4,65 (2/43) idi. ICP4 geninin nükleik asit dizileri GenBank'taki ILTV dizileri ile karşılaştırıldığında benzerlik \% 96.82 ile \% 100 arasında değiștiği görüldü. Örneklerin sekans dizileri TCO suşları ile karșılaştırıldı̆̆ında \% 99.77100 homoloji gözlemlendi. HgaI enzimi ile yapılan sanal RFLP analizinde, çalışmadaki suşlar TCO aşı suşuna benzer bir paterne sahip olarak karakterize edildi. Bu araştırma, köy tavuklarında GaHV1'in varlığını ve karakterizasyonunu ortaya koyan ilk çalışmadır. Türkiye'de ILT prevalansını tahmin etmek için büyük ölçekli çalışmalara ihtiyaç vardır. ILTV salgınlarını kontrol etmek için tavuklar izlenmeli ve yetiştiriciler aşılanmamış tavuklarla aşılanmış olanların temas etmesinden kaçınmalıdır.

Anahtar Kelimeler: GaHV1, infeksiyöz laringotrakeitis, köy tavuğu, RFLP, sekans

To cite this article: Kalın R. Turan T. Issdan H. Molecular Detection and Characterization of Infectious Laryngotracheitis Virus in Backeyard Chickens in Turkey. Kocatepe Vet J. (2020) 13(4):332-339. 


\section{INTRODUCTION}

Infectious laryngotracheitis (ILT) is one of the important disease that included in contagious respiratory infections of chickens. Gallid herpesvirus I (GaHV1) also known as infectious laryngotracheitis virus is responsible for infection and classified in the family Herpesviridae, subfamily Alphaherpesvirinae, genus Iltovirus, with a linear double-stranded DNA which is approximately $150 \mathrm{~kb}$ size (King, et al. 2018, Thureen and Keeler 2006). Infection causes production loss, low growth rates, and mortality. Inflammation predominantly affects mucosal surfaces such as conjunctiva, larynx, trachea and hemorrhagic, necrotic tracheal lesions may be seen in diseased flocks. Chickens that are infected with ILT show clinical signs including lacrimation, nasal discharge, conjunctivitis, respiratory distress, dyspnea, coughing, bloody mucus secretion, decreased egg production and dead (Guy and Garcia 2008).

The respiratory and ocular routes are important ways of transmission between birds although vertical infection has not been verified yet. Main sources of viruses are known as sick chickens, latent carriers, contaminated litter and drinking water. Biofilm formation of some bacteria may be affective on remaining of virus in environment $(\mathrm{Ou}$ and Giambrone 2012).

Live-attenuated vaccines have been developed and widely used against the disease. Strains were derived by serial passages in chicken embryos (CEO; chickenembryo origin) or in cell culture (TCO; tissue culture origin) and used in commercial layers, layer breeders, and broiler breeders (Oldoni and García 2007). Several CEO and TCO vaccines are commercially available. Besides their protection, these vaccines may revert to virulence due to bird to bird passage or reactivation of latent strains (Guy et al. 1990, Hughes et al. 1991, Kotiw et al. 1995). It has been reported that vaccinated birds may be a source of disease for non-vaccinated flocks (Blacker et al. 2011).

Virus isolation, serological and molecular tests are widely used for the detection of infection. Enzymelinked immunosorbent assay (ELISA), serum neutralization tests, agar gel immunodiffusion and fluorescent antibody tests can be applied to investigate antibodies in serum samples (OIE 2019). Serological tests and virus isolation methods are time consuming and require skilled personnel.

Polymerase chain reaction (PCR) is more sensitive than serological tests and preferred as an alternative to virus isolation for diagnosis of ILT because of the rapid, specific, and simplex properties of the method (Creelan et al. 2006, Oldoni and García 2007). Primers targeting the infected-cell protein 4 (ICP4) gene regions are used in many studies for the detection of virus by PCR and giving trustful results (Blakey et al. 2019, Bayoumi et al. 2020). DNA detection has been successfully performed to identify agent in clinical samples including trachea, larynx and conjunctiva. GaHV1 has also been detected in internal organs of chickens including heart, liver, spleen, lung, kidney, thymus, glandular stomach, duodenum, pancreatic gland, small intestine, large intestine, cecum, cecal tonsil, bursa fabricius and brain by PCR method (Zhao et al. 2013)

It is difficult to differentiate whether the new outbreaks are caused by vaccine strains or field strains. Sequencing and restriction fragment length polymorphism (RFLP) methods were performed to clarify the epidemiology of infections. RFLP involves differentiation of strains by restriction enzyme cleavage patterns of digested genes (Oldoni and García 2007, Yan et al. 2016).

Few studies have been conducted in broiler breeders, layer hens in Turkey and there is no data about the existence of ILT in backyards. The purpose of the study was to document the detection and characterization of GaHV1 in backyard chickens using PCR and sequencing.

\section{MATERIAL and METHODS}

\section{Sampling}

Tracheal swap samples were taken from chickens which have nasal discharge, dyspnea and coughing. During the study 163 animals were sampled between November 2018 and March 2019. Specimens were collected from 43 backyard flocks located in 12 different location around Sivas province. Chicken numbers were between 10 and 30 in each flock. The examined flocks were at 25-35 weeks age and all flocks were not vaccinated against ILT.

\section{DNA extraction and PCR}

Tracheal swabs were suspended in $2 \mathrm{ml}$ of $1 \mathrm{M}$ sterile PBS and centrifuged for $10 \mathrm{~min}$ at $3,500 \mathrm{rpm}$ to remove large cellular debris. DNA was extracted from the supernatants using a GF-1 Viral Nucleic Acid Extraction Kit (Vivantis Technologies, Malaysia) according to the manufacturer's instructions. Eluted nucleic acids were kept at $-80^{\circ} \mathrm{C}$ until use.

The ICP4 gene specific primers (ILTF 5' CCTCGACGCCGAGTAATTT 3 ' and ILTR 5' GAGCGAGTCGATGACCGTAT 3') designed by Wanasawaeng and Chansiripornchai (2010) were used. Amplification was performed in Bio-Rad T100 ${ }^{\mathrm{TM}}$ Thermal Cycler in a reaction volume of $50 \mu \mathrm{l}$, containing $5 \mu \mathrm{l}$ of 10X PCR buffer, $5 \mu \mathrm{l}$ of $25 \mathrm{mM}$ $\mathrm{MgCl}, 10 \mathrm{mM}$ of deoxynucleotide triphosphate, $5 \mathrm{U}$ of Taq DNA polymerase (Vivantis, Germany), 10 pmol each primer and $25 \mathrm{ng}$ template DNA. The PCR was incubated through one cycle of $95 \mathrm{C}$ for 3 min, then 40 cycles of $94 \mathrm{C}$ for $30 \mathrm{sec}, 52 \mathrm{C} 30 \mathrm{sec}$ and $72 \mathrm{C}$ for $1 \mathrm{~min}$, and finally one cycle of $72 \mathrm{C}$ for $10 \mathrm{~min}$. The amplified products were detected by staining with ethidium bromide $(0.5 \mathrm{mg} / \mathrm{ml})$ after electrophoresis at $80 \mathrm{~V}$ for $2 \mathrm{~h}(7 \mathrm{~V} / \mathrm{cm})$ in $1.5 \%$ agarose gels. 


\section{Sequencing and RFLP analysis}

PCR amplicons (440 bp) of three positive field samples were sequenced. Two DNA samples from F location and one from $\mathrm{H}$ location were randomly selected and investigated further by partial sequence analysis. Phylogenetic analyses and molecular relationship of viruses were interpreted with Geneious Prime Version 2020.2.2 software (Kearse et al. 2012).

RFLP analysis was implemented to the partial sequences of ICP4 gene of strains using the in silico Virtual Gel plugin for Geneious Version 2020.2.2 (Kearse et al. 2012). For this purpose a previous Turkish strain (MH921826.1), a TCO vaccine strain (JN580312.1), two CEO vaccine strains (HM230782.1 and EU104900.1) and three strains (MN717261.1, MN717262.1 and MN717263.1) obtained from present study were investigated.

\section{RESULTS}

\section{PCR findings}

According to the Wanasawaeng and Chansiripornchai (2010) the primers should have provide amplicons of $428 \mathrm{bp}, 440 \mathrm{bp}$ and $450 \mathrm{bp}$ from CEO, TCO and filed isolates, respectively. Only $440 \mathrm{bp}$ amplicons obtained in this study. Of the 163 DNA samples, 5 $(3.07 \%)$ were found to be positive for ILT infection. Four samples were belong to one flock in $\mathrm{F}$ location and one sample was belong to a flock in $\mathrm{F}$ location. Positivity was $4.65 \%(2 / 43)$ at flock level (Table 1).

\section{Phylogenetic analysis findings}

Partial ICP4 sequences of three positive field samples were used for subsequent phylogenetic analysis. Two samples from $\mathrm{F}$ location and one from $\mathrm{H}$ location were compared and investigated. The partial nucleotide and amino acid sequences of chosen samples were deposited to the GenBank with accession numbers as follows: MN717261 (ILTV/TUR/7), MN717263 (ILTV/TUR/74) and MN717262 (ILTV/TUR/66). Sequences of two samples gathered from same flock in $\mathrm{F}$ location (MN717261, MN717263) were homolog with each other. The last one in H location was (MN717262) showed one nucleotide difference than others. The nucleic acid sequences of the ICP4 gene compared with overall the ILTV sequences in GenBank and the level of identity differed from 96.82 to $100 \%$. When the sequences of samples taken in the present study compared with TCO strains $99.77-100 \%$ homology was observed. Besides, samples showed 96.82-97.32 homology with $\mathrm{CEO}$ strains because of the presence of deletions including 12 nucleotides in CEO strains. The phylogenetic tree data showed that the ICP4 genes of TCO like strains and CEO like strains (Table 2) were divided into two different branches (Fig. 1).

\section{RFLP findings}

Selected strains were further analyzed by RFLP using $\mathrm{HgaI}$ restriction enzyme with the in silico Virtual Gel plugin for Geneious Version 2020.2.2. The DNA sequences of same region of the gene of previous Turkish strain (MH921826.1), TCO vaccine strain (JN580312.1), CEO vaccine strains (HM230782.1 and EU104900.1) and three strains (MN717261.1, MN717262.1 and MN717263.1) detected in present study were digested in silico to characterize isolates. Two different RFLP patterns were observed for CEO, TCO and Turkish field strains. The CEO vaccine strain was digested to $414 \mathrm{bp}$ and $14 \mathrm{bp}$ fragments. The TCO vaccine strains and Turkish field strains showed three DNA fragments of 250, 176 and 14 bp (Fig. 2).

Table 1. Distribution of samples and flocks

\begin{tabular}{|c|c|c|}
\hline Location & Flocks/Positive flocks & Samples/Positive samples \\
\hline A & 4/- & 10/- \\
\hline B & $3 /-$ & 8/- \\
\hline C & $5 /-$ & $20 /-$ \\
\hline D & $3 /-$ & $13 /-$ \\
\hline $\mathrm{E}$ & $2 /-$ & $10 /-$ \\
\hline F & $5 / 1$ & $23 / 4$ \\
\hline G & 3/- & 11/- \\
\hline $\mathrm{H}$ & $6 / 1$ & $19 / 1$ \\
\hline I & 4/- & 14/- \\
\hline J & 2/- & 9/- \\
\hline K & 5/- & $21 /-$ \\
\hline $\mathrm{L}$ & 1/- & $5 /-$ \\
\hline Total & $43 / 2$ & $163 / 5$ \\
\hline
\end{tabular}


Table 2. GenBank accession numbers of GaHV1 strains used in genetic analysis.

\section{Strain}

ILTV/TUR/7/Turkey (present study)

ILTV/TUR/66/Turkey (present study)

ILTV/TUR/74/Turkey (present study)

TR2-70-1/Turkey

Composite of 6 (RefSeq)/USA

ILTV.29/19/Australia

SA2/Australia

ILTVclass10/Australia

S2.816/Australia

CSW-1/Australia

2009/1643/Russia

VFAR-043/Peru

USDA/USA

2/A/04/BR/USA

TCO_IVAX/VACCINE/USA

ILTV/Brazil/2012/472-3/Brazil

V1-99/Australia

CL9/Australia

ILTV.358/19/Australia

0206/14/Ko/South_Korea

KR_1020170134159-A/15/VACCINE/South_Korea

2013/2701/Russia

WG/China

Jiang-2011-3/China

193435/07/Italy

CEO_Intervet/VACCINE/Italy

ILT.77.IR_Iran

63140/C/08/BR/USA

CEO_VACCINE/USA
Accession Number

MN717261.1

MN717262.1

MN717263.1

MH921826.1

NC006623.1

MK894996.1

JN596962.1

KR822401.1

MF417807.1

JX646899.1

MF405079.1

MG775218.1

JN542534.1

EU104912.1

JN580312.1

KP768193.1

JX646898.1

JN804827.1

MK895003.1

MH937564.1

LY517296.1

MF405080.1

JX458823.1

JN969100.1

KP677883.1

HM230782.1

KX344451.1

JN542536.1

EU104900.1 


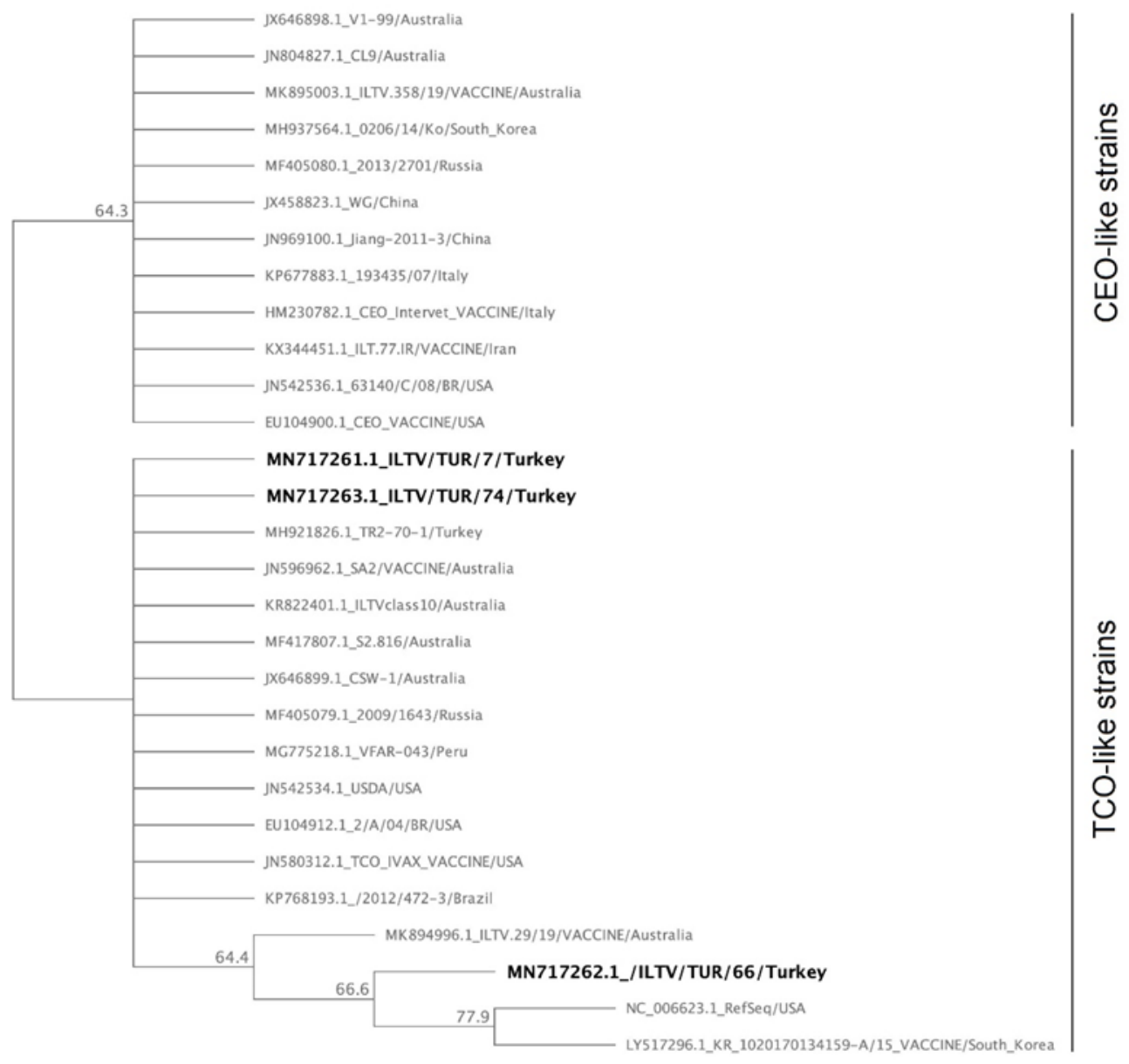

Figure 1. The phylogenetic tree of ICP4 genes of TCO like strains and CEO like strains.

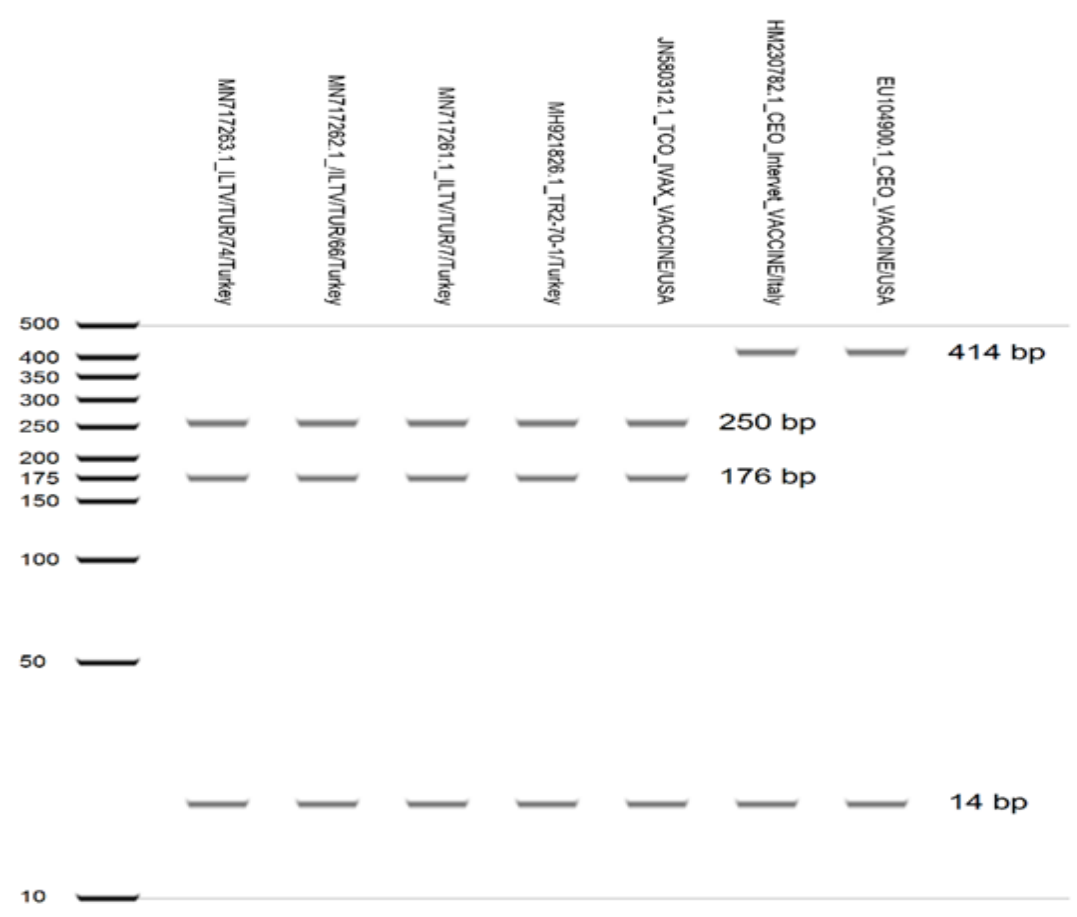

Figure 2. The restriction model of gel electrophoresis of the strains analyzed in Virtual Gel plugin for Geneious. Lane 1: Ladder, Lane 2-8: The RFLP patterns of CEO, TCO and Turkish field isolates cut by HgaI. 


\section{DISCUSSION}

This is the first study that presents the situation of ILT infection in backyards. Tracheal swab samples were collected and examined in a four month period by PCR. The frequency of the disease in backyard chickens estimated as $3.07 \%$ and two flocks were positive $(4.65 \%)$ within the 43 . Results of present study showed that GaHV1 is not widely distributed in backyard chicken flocks in Turkey. So far, only a few studies have been conducted in Turkey although the ILT is one of the well-known respiratory diseases of poultry and seen throughout the world. It was firstly reported in Elazı ğ province in nine white leghorns (Gülaçt1 et al. 2007). In 2016 five tracheal samples of broiler breeders (located in Mediterranean region) have been examined and three of them have been detected as positive for GaHV1 (Kaya and Akan 2018). Aras et al. (2018) have investigated commercial layer hens serologically in a six month period in Konya and they have indicated the disease as 64\% $(16 / 25)$ and $42.6 \%(266 / 625)$ at flock and samples levels, respectively. There was no vaccination history for ILT in these three studies. They have reported that ILT was observed in layers and broiler breeders. However, no adequate data are available for the potential of ILT at the national level in Turkey, and it is not easy to estimate the degree of threat that it acts to the poultry population. Similarly, none of the flocks had been vaccinated against the ILT in the present study. The positivity rates of backyards were quite lower than Aras et al (2018) and this difference may be related with the sensitivity of ELISA tests. Virus isolation and serological tests (fluorescent antibody technique, enzyme-linked immunosorbent assay, serum neutralization, and agar gel immunodiffusion) have been used for diagnoses but, these methods are laborious, time consuming and the sensitivities of serological tests are lower than PCR (Alaraji et al. 2019).

ILT continue to keep its importance throughout the world. It had been firstly reported in the USA in 1925 and over 100 countries have declared the disease so far (Menendez et al. 2014). Countries including USA, Canada, Brazil, Europe, Australia, China, Egypt, South Asia, Lebanon and Saudi Arabia have notified ILT outbreaks (Gowthaman et al. 2020). Lastly, the disease have been reported in Iraq (Alaraji et al. 2019) and Namibia (Molini et al. 2019). In Turkey, the frequency of the disease that determined in present study is lower than other countries. In previous studies samples have been taken from commercial flocks in poultry industry (layers, broilers) although the material of this study was backyards. Besides, we know that many countries had been demonstrating live ILT vaccination and vaccines are not fairy innocent. Vaccines may cause latent infections (Hughes et al. 1991) and infected birds may be a source of disease (Blacker et al. 2011) for non- vaccinated flocks in those countries. In latent or some recovered birds, the virus may pass a non-infectious state and reside in, so the chickens appear to be healthy (Williams et al. 1993). ILT spreads from bird to bird aerogenically, via fomites. Vertical transmission or wild bird infection has not been reported yet (Gowthaman et al. 2020).

In present study the ICP4 gene of GaHV1 characterized partially and confirmed that the viral agent present in backyard chickens in Turkey. Genetic relationships of GaHV1 strains and phylogenetic positions of Turkish strains were also demonstrated. The viruses detected in Turkey, shared a high nucleotide similarity (96.82 to100\%). The sequence analysis shows that the strains detected in this study shares a high similarity with the other GaHV1 strains worldwide. Two clusters observed when the sequences of USA, Australia, Russia, Peru, Brazil, South Korea, China, Italy, Iran and Turkey compared (fig 1). Broilers, broiler breeders, layers, and layer breeders are usually vaccinated with CEO and/or TCO vaccines in many countries. The sequences of ICP4 genes of CEO and TCO vaccine strains deposited to the GenBank had been investigated and differences had been reported between CEO and TCO vaccine strains (Wanasawaeng and Chansiripornchai 2010). The nucleotides at the position of 272-283 were missing in the CEO vaccine strain and this deletion had been used for the differentiation of strains by RFLP. The PCR-RFLP patterns of several genome regions have been very useful to search genetic diversity within the GaHV1 genome, and to distinguish filed and vaccine strains (Bayoumi et al. 2020). The virtual RFLP analysis characterized all of the strains (detected in present study) as having a pattern similar to the vaccine strain TCO. Digestion with the $H g a \mathrm{I}$ restriction enzyme showed 414 and 14bp bands for the CEO vaccines. TCO vaccine and the tested samples represented three bands (250, 176 and 14bp in length). Wanasawaeng and Chansiripornchai (2010) declared that 428, 440 and 450 bp amplicons should be provided from $\mathrm{CEO}$, TCO and filed isolates, respectively with recommended primer set. A $440 \mathrm{bp}$ amplicons and TCO like RFLP patterns (three bands: 250, 176 and 14bp) were observed. Samples detected in present study were not field isolate (not amplified 450 bp bands) besides sequences of the Turkish strains were very similar with TCO vaccine strains in GeneBank and were located in TCO-like strains (fig 1). These may be explained with the circulation of a TCO vaccine strain and it may be passed from commercial birds to backyards. In contrast, studies conducted in US indicated that most of ILTV outbreaks are caused by CEO vaccine isolates that circulating in longlived bird operations and spill-over broiler populations (Oldoni and García 2007).

In conclusion, this study revealed that ILT has migrated to backyard chickens. This is the first report 
of presence and characterization of GaHV1 in backyards. Chicken meat and eggs, which contain high-quality protein, vitamins, and minerals for the human are the important and cheapest source of animal proteins. Although the commercial poultry industry dealing with this necessity, people raising their own birds in rural and suburban areas all over the world. Besides, poultry products are important commodity of Turkish livestock economy. Large scale studies including commercial layer hens, broilers and backyards are needed to estimate prevalence and incidence of ILT infections in Turkey. It is not clear to understand the direction of the disease which may be transmitted from commercial chickens to backyards or opposite. Therefore characterization of Turkish ILTV strains (by sequencing or RFLP) is essential to clarify the epidemiology of infections and to compare with vaccine strains applied in our country. Additionally chickens should be monitored and growers should avoid to contacting vaccinated or recovered birds with non-vaccinated chickens, to control ILTV outbreaks. Management, biosecurity, rapid detection, effective vaccination protocols, collaboration of the government-poultry industryveterinarians-growers are critical for the prevention and the control of the disease.

Conflict of Interest: The authors declare that they have no conflict of interest.

\section{REFERENCES}

Alaraji F, Hammadi H, Abed AA, Khudhair YI. Molecular detection and phylogenetic tree of infectious laryngotracheitis virus in layers in Al-Diwaniyah province, Iraq. Veterinar World. 2019; 12(4): 605-608.

Aras Z, Yavuz O, Gölen GS. Occurrence of infectious laryngotracheitis outbreaks in commercial layer hens detected by ELISA. Journal of Immunoassay and Immunochemistry. 2018; 39:2, 190-195. doi: 10.1080/15321819.2018.1428991.

Bayoumi M, El-Saied M, Amer H, Bastami M, Sakr EE, ElMahdy M. Molecular characterization and genetic diversity of the infectious laryngotracheitis virus strains circulating in Egypt during the outbreaks of 2018 and 2019. Arch Virol. 2020; 165(3):661-670. doi:10.1007/s00705-019-04522-4.

Blacker H, Kirkpatrick N, Rubite A, O'Rourke D, Noormohammadi A. Epidemiology of recent outbreaks of infectious laryngotracheitis in poultry in Australia. Australian Veterinary Journal. 2011; 89(3):89-94. doi:10.1111/j.1751-0813.2010.00665.x.

Blakey J, Stoute S, Crossley B, Mete A. Retrospective analysis of infectious laryngotracheitis in backyard chicken flocks in California, 2007-2017, and determination of strain origin by partial ICP4 sequencing. J Vet Diagn Invest. 2019; 31(3):350-358. doi:10.1177/1040638719843574.

Creelan JL, Calvert VM, Graham DA, McCullough SJ. Rapid detection and characterization from field cases of infectious laryngotracheitis virus by real-time polymerase chain reaction and restriction fragment length polymorphism. Avian Pathol. 2006; 35:173-179.

Gowthaman V, Kumar S, Koul M, Dave U, Murthy T, Munuswamy P, Tiwari R, Karthik K, Dhama K, Michalak I, Joshi SK. Infectious laryngotracheitis: Etiology, epidemiology, pathobiology, and advances in diagnosis and control - a comprehensive review. The veterinary quarterly. 2020; 40(1):140-161. doi:10.1080/01652176.2020.1759845.

Gülaçtı I, Bulut H, Eröksüz Y, Çeribaşı AO. Outbreak of clinical infectious laryngotracheitis in Turkey. Vet. Rec. 2007; 160: 554-555. doi: 10.1136/vr.160.16.554.

Guy JS, Barnes HJ, Smith L. Increased virulence of modifedlive infectious laryngotracheitis vaccine virus following bird to-bird passage. Avian Dis. 1990; 35:348 https ://doi.org/10.2307/15911 88 .

Guy JS, Garcia M. Laryngotracheitis. In: Disease of poultry, Ed; Saif YM, Fadly AM, Glisson JR, McDougald LR, Nolan LK, Swayne DE, 11th ed. Ames: Iowa State University Press, 2008; pp. 137-152 35.

Hughes CS, Williams RA, Gaskell RM, Jordan FTW, Bradbury JM, Bennett $\mathbf{M}$, et al. Latency and reactivation of infectious laryngotracheitis vaccine virus. Arch Virol. 1991; 121:213-218.

Kaya BI and Akan M. First report of avian infectious laryngotracheitis infection in broiler breeders in Turkey. Ankara Üniversitesi Veteriner Fakültesi Dergisi. 2018; 65: 331-334.

Kearse M, Moir R, Wilson A, et al. Geneious Basic: an integrated and extendable desktop software platform for the organization and analysis of sequence data. Bioinformatics. 2012; 28(12):1647-1649. doi:10.1093/bioinformatics/bts199.

King AMQ, Lefkowitz EJ, Mushegian AR. et al. Changes to taxonomy and the international code of virus classification and nomenclature ratified by the international committee on taxonomy of viruses. Arch Virol. 2018; 163, 2601-2631. https://doi.org/10.1007/s00705-018-3847-1.

Kotiw M, Wilks CR, May JT. The effect of serial in vivo passage on the expression of virulence and DNA stability of an infectious laryngotracheitis virus strain of low virulence. Vet Microbiol. 1995; 45:71-80. https://doi.org/10.1016/0378-1135(94)00115-D.

Menendez KR, Garcia M, Spatz S, Tablante NL. Molecular epidemiology of infectious laryngotracheitis: a review. Avian Pathol. 2014; 43(2):108-117.

Molini U, Aikukutu G, Khaiseb S. et al. Investigation of infectious laryngotracheitis outbreaks in Namibia in 2018. Trop Anim Health Prod. 2019; 51: 2105-2108 https://doi.org/10.1007/s11250-019-01918-x.

Oldoni I, García M. Characterization of infectious laryngotracheitis virus isolates from the US by polymerase chain reaction and restriction fragment length polymorphism of multiple genome regions. Avian Pathol. 2007; 36: 167-176. 
Ou SC, Giambrone JJ. Infectious laryngotracheitis virus in chickens. World J Virol. 2012; 1(5): 142-149. doi: http://dx.doi.org/10.5501/wjv.v1.i5.142.

Thureen DR and Keeler CL. Psittacid herpesvirus 1 and infectious laryngotracheitis virus: Comparative genome sequence analysis of two avian alphaherpesviruses. J. Virol. 2006; 80:7863-7872.

Wanasawaeng $W$ and Chansiripornchai N. Molecular classification of infectious laryngotracheitis virus from chick embryo origin vaccine, tissue culture origin vaccine and field isolates. Thai J. Vet. Med. 2010; 40:393-398.

Williams RA, Bennett M, Bradbury JM, Gaskell RM, Jones RC, Jordan FTW. Demonstration of sites of latency of infectious laryngotracheitis virus using the polymerase chain reaction. Journal of General Virology. 1993; 73: 2415242.

World Organisation for Animal Health (OIE). Manual of Diagnostic Tests and Vaccines for Terrestrial Animals 2019 Chapter 3.3.3. Avian infectious laryngotracheitis. OIE, Paris. Available at: https://www.oie.int/fileadmin/Home/eng/Health_stand ards/tahm/3.03.03_AVIAN_INF_LARYNGO.pdf.

Accession date: 02.07.2020.

Yan Z, Li S, Xie Q, Chen F, Bi Y. Characterization of field strains of infectious laryngotracheitis virus in China by restriction fragment length polymorphism and sequence analysis. J Vet Diagn Invest. 2016; 28(1):46-49. doi:10.1177/1040638715618230.

Zhao Y, Kong C, Cui X, Cui H, Shi X, Zhang X, Hu S, Hao

L, Wang Y. Detection of infectious laryngotracheitis virus by real-time PCR in naturally and experimentally infected chickens. PLoS One. 2013; 8(6):e67598. 